НАУКОВИЙ ВІСНИК

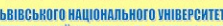

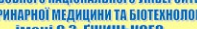
імені С.3. гжищьког Scientific messenger of Livi National Unirersity
Veterinary Medicine and Biotechnologies

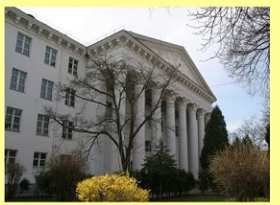

СЕРІЯ “ЕКОНОМІчн НАУКИ"

Том 21 № 93 2019

Науковий вісник Львівського національного університету ветеринарної медицини та біотехнологій імені С.3. Гжицького. Серія: Економічні науки

\author{
Scientific Messenger of Lviv National University \\ of Veterinary Medicine and Biotechnologies. \\ Series: Economical Sciences
}

UDC 338.43.01

\title{
Actual problems of price formation for agricultural products
}

\author{
O. Salamin
}

Stepan Gzhytskyi National University of Veterinary Medicine and Biotechnologies Lviv, Ukraine

Article info

Received 04.09.2019

Received in revised form 03.10 .2019

Accepted 04.10.2019

Stepan Gzhytskyi National University of Veterinary Medicine and Biotechnologies Lviv, Pekarska Str., 50, Lviv, 79010, Ukraine.

Tel.: +38-099-237-30-02 E-mail: oksana_salamin@i.ua
Salamin, O. (2019). Actual problems of price formation for agricultural products. Scientific Messenger of Lviv National University of Veterinary Medicine and Biotechnologies. Series: Economical Sciences, 21(92), 17-22. doi: 10.32718/nvlvet-e9304

The problems of prices formation for agricultural products are analyzed. In Ukraine, prices have been liberalized without market environment, unlike economically developed countries, where the market environment has evolved over a long period of time. This has led to high price volatility, which is very difficult for manufacturers to adapt. They cannot develop business plans and marketing programs. Due to high risk, bank loans cannot be attracted. The effectiveness of direct financial support programs is decreasing. They did not ensure the overcoming of monopoly tendencies in the field of product purchases and stabilization of the prices of efforts of state agricultural management and public organizations aimed at establishing marketing cooperatives. The cooperative products are sold to the processing plants at the same prices at which they would be harvested and sold without setting up a cooperative. Such cooperatives only simplify the activities of processing enterprises for the procurement of raw materials. Cooperatives, which carry out the processing of products, are viable ones that influence the level of prices and stabilize them. This forms a self-regulatory vertical marketing system of the cooperative type. Without government intervention, prices are acceptable that are acceptable both, for the production and promotion and sale of products to the end consumer. Prices are promptly revised in the light of market conditions and problems that arise at individual levels of the supply chain. Auction results have a significant impact on the overall level and dynamic price changes. The information on the results of the bidding affects the price level, which is formed by all other alternative sales channels. Monopolistic tendencies by individual market participants in the field of agricultural purchases are often only possible due to the lack of information on market conditions from individual producers and possible price in alternative distribution channels. All wholesale agricultural markets established in Ukraine are of a supply nature. They operate in large cities and create the conditions for manufacturers to produce manufactured products, but require trading operations throughout the day. Such markets are more appropriate for intermediary structures that operate on a permanent basis. For the manufacturers of products, wholesale wholesale markets that are created in the areas of production of raw materials are more acceptable. The founders of such markets are usually sales cooperatives. Large cooperative lots of homogeneous products can be offered in such markets by cooperatives in such markets. Auctions may be organized and conducted for such products.

Key words: price, market price generation, agrarian market infrastructure, market monopolization, auction bidding.

\section{Актуальні проблеми формування цін на сільськогосподарську продукцію}

\author{
О.С. Саламін
}

Львівський національний університет ветеринарної медицини та біотехнологій імені С.3. Гюсицького, м. Львів. Україна

Аналізуються проблеми формування цін на сільськогосподарську продукцію. На відміну від економічно розвинутих краӥн, де ринкове середовище формувалось еволючійно протягом тривалого періоду часу в Україні иіни були лібералізовані без такого сформованого ринкового середовища. Це призвело до проявів монопольних тендениій, високої мінливості иін, адаптуватись до яких виробникам продукиї дуже складно. Вони не можуть розробляти обтрунтованих бізнес-планів та маркетингових програм. Через висо- 
кий ризик не можуть залучатись банківські кредити. Знижується ефективність програм прямої державної фінансової підтримки. Не забезпечили подолання монопольних тенденцій у сфері закупівель продукції та стабілізацію ціін зусилля державних органів управління сільським господарством та громадських організачій, спрямовані на створення збутових кооперативів. Заготовлена кооперативами продукиія збувається на переробні підприємства за тими ж иінами, за якими вона заготовлялась би $і$ збувалась без створення кооперативу. Такі кооперативи лише спрошують діяльність переробних підприємств із заготівель сировини. Життєздатними, такими, щзо здійснюють вплив на рівень цін і їх стабілізацію є кооперативи, які крім заготівель, здійснюють переробку продукиії. Цим формується саморегулівна вертикальна маркетингова система кооперативного типу. Тут без державного втручання формуються ціни, прийнятні як для сфери виробництва, так і сфери просування і реалізацї продукції кінцевому споживачу. Ціни оперативно переглядаються з урахуванням кон'юнктури ринку і проблем, щзо виникають на окремих рівнях збутового ланцюга. Значний вплив на загальний рівень і динамічні зміни иін мають результати аукційних торгів. Інформація про результати торгів впливає на рівень ціни, щзо складається за усіма іншими альтернативними каналами збуту продукції. Монопольні тенденції, щзо здійснюють окремі учасники ринкових відносин у сфері закупівель сільськогосподарської продукиії, часто можливі лише через відсутність в окремих виробників продукції інформації щзодо кон'юнктури ринку і можливої ціни в альтернативних каналах розподілу. Усі створені в Украӥні оптові ринки сільськогосподарської продукції мають постачальницький характер. Вони функціонують y великих містах і створюють умови для реалізації виробниками виробленої продукції, але вимагають здійснення торговельних операцій протягом мало не всього дня. Такі ринки більш прийнятні для посередницьких структур, які здійснюють комерційну діяльність на постійній основі. Для виробників продукиії прийнятніші оптові ринки збутового типу, які створюються у зонах виробництва сировини. Засновниками таких ринків, зазвичай, є збутові кооперативи. Збутовими кооперативами на таких ринках можуть пропонуватись великі товарні партії однорідної продукції. Щодо такої продукції можуть організовуватись та здійснюватись аукційні торги.

Ключові слова: ичіна, закупівельна ичіна, ринкове генерування ичін, інфраструктура аграрного ринку, монополізація ринку, аукиійні торги.

\section{Вступ}

Проблеми ціни і ціноутворення постійно перебувають у полі зору вчених економістів та практиків господарювання. Обумовлено це значущістю ціни, іiі впливом на відтворювальний процес у будь-якій галузі. Саме рівнем і динамічними змінами ціни визначаються обсяги виробництва продукції. В умовах ринкових відносин ціна може забезпечити як процвітання галузі чи підприємства, так і їх занепад. Однією 3 основних проблем ціноутворення, що дискутується у наукових публікаціях, є проблема диспаритету цін на сільськогосподарську і промислову продукцію (Marmul, 2014; Rosokha \& Sharapa, 2016; Semenda et al., 2018). К.В. Бондаревська вважає основною причиною диспаритету цін неналежне їхнє державне регулювання, яке посилюється відсутністю прозорих ринкових відносин, низькою платоспроможністю споживачів сільськогосподарської продукції, демпінговим ціноутворенням експортерів продуктів сільського господарства і вимушеними закупівлями для цього у виробників продукції за заниженими цінами (Коvalenko et al., 2013; Bondarevska, 2014; Shpychak, 2016). А.М. Ужва причину диспаритету цін вбачає у відсутності в сільгоспвиробників досвіду ціноутворення (Uzhva, 2016). Значна увага до проблем ціноутворення поєднується $з$ тим, що до цього часу не сформовано загальноприйнятних підходів до оцінки причин, які порушують нееквівалентні відносини між підприємствами, що належать до різних галузей та обгрунтуванню способів удосконалення процесів ціноутворення. Більшість підходів, що пропонуються, $\epsilon$ дискусійними. Роздуми провокує твердження про неможливість подолання проблем ціноутворення ринковими методами (Bondarevska, 2014). Суперечливими є підходи до оцінок результатів експерименту, який полягав у відмові державних органів від регулювання цін на соціально значущі товари.

Метою статті $є$ аналіз основних проблем ціноутворення на сільськогосподарську продукцію та альтернативних точок зору представників різних наукових шкіл та течій щодо способів їх вирішення, дослідження впливу рівня та співвідношення цін на обсяги виробництва основних видів сільськогосподарської продукції. Для досягнення мети вирішувались завдання: виявити основні причини високої мінливості цін на сільськогосподарську продукцію; оцінити вплив рівня і динамічних змін ціни на можливості адаптації до неї виробників продукції; запропонувати способи забезпечення ринкового генерування цін та їхньої стабілізації.

\section{Матеріали і методи досліджень}

Дослідження здійснювались на основі застосування загальноприйнятих методів. Монографічний метод використано для виявлення проблем формування цін на сільськогосподарську продукцію, їх волатильності та впливу на можливості адаптації виробників продукції до ринкового середовища, економікостатистичний метод - для оцінки динамічних змін рівня цін та прибутковості господарської діяльності, яка при цьому складається.

\section{Результати та їх обговорення}

Чинників, що стримують реалізацію можливостей вітчизняного сільського господарства, багато. Основним серед них є рівень ціни на сільськогосподарську продукцію, іiі співвідношення з цінами на продукцію інших галузей. Ціна $є$ центральним елементом ринкового механізму господарювання, і у ній, як у фокусі, по-перше, концентруються мало не всі економічні проблеми. По-друге, ціна здійснює визначальний вплив на поведінку суб'єктів господарювання та результати господарської діяльності. 3 урахуванням цього закономірними є багатопланові підходи до вивчення цін та аналізу процесів ціноутворення. При цьому висхідними у розробці концепцій удосконалення ціноутворення на сільськогосподарську продукцію $\epsilon$ підходи до пошуку способів подолання більшості економічних проблем на засадах ринкового ціноутво- 
рення, основною ознакою якого є вільне формування цін. Такий підхід до ціноутворення $\epsilon$ визначальним навіть тому, що обмежені можливості державного втручання у процеси ціноутворення на сільськогосподарську продукцію визначені міжнародними угодами, укладеними Україною під час набуття членства у СОТ та асоційованої участі в Європейському Союзі. Все ж тривале реформування аграрного сектору на засадах ринкових відносин і лібералізації ціноутворення не забезпечило очікуваних результатів. Свідченням безпідставності абсолютизації вільного ціноутворення $є$ результати реформ у післясоціалістичних країнах Східної Європи на засадах “шокової терапії”, де лише на основі поєднання впливу ринкових важелів ціноутворення та державного регулювання цін досягались очікувані результати. Абсолютно вільне ціноутворення можливе лише в умовах атомістичного ринку, який за побудовою близький до моделі чистої конкуренції. Відхилення від даної моделі породжує ринкову владу окремих учасників ринкових відносин, які монополізують ринок і здійснюють визначальний вплив на ціну. На відміну від більшості економічно розвинутих країн, де ринкові відносини формувались еволюційно тривалий період часу і набуто досвід впливу державних органів управління на організацію ринку, в Україні за показник економічного прогресу до 1990 року видавався рівень усуспільнення виробництва. Це призводило до зростання рівня концентрації виробництва і скорочення кількості суб'єктів ринкових відносин. В умовах лібералізації ціноутворення це призвело до формування монопольних тенденцій і закономірного в такій ситуації результату - посилення кризових явищ. Недосконала структура ринку поєднувалась 3 відсутністю досвіду державного впливу на ціну в умовах ринкових відносин. Пропонувались підходи, характерні для планової економіки - формування ціни на основі норми прибутку, прямої індексації ціни 3 урахуванням темпів інфляції. Обгрунтовано вбачаючи відповідальними за рівень ціни і результати, які при цьому формуються закупівельні організації, що монополізували ринок, поширені рекомендації щодо зменшення кількості посередницьких структур. До уваги не береться те, що зменшення кількості посередницьких структур призводить до посилення монополізації сфери закупівель і реалізації сільськогосподарської продукції, звуження ринків, на які продукція виводиться. Необхідною умовою появи нових посередників, особливо тих, які збільшують довжину маркетингового каналу, є можливість розширення ринків збуту, виявлення ринкових сегментів, на яких попит не задоволений і на яких продукцію можна пропонувати за порівняно вищими цінами. Не досягали очікуваних результатів намагання подолати інфляційні процеси i забезпечити доступність соціально значущих продовольчих товарів, обмеження рівня рентабельності. Закономірним результатом такого обмеження, зазвичай, $€$ зменшення обсягів виробництва продукції, посилення іiі дефіцитності та подальшого зростання цін на неї. Зберегти низькі ціни на дефіцитну продукцію в умовах ринкових відносин неможливо. Дефіцит продукції долається вимушеним збільшенням iї імпорту, що поєднується з втратою вітчизняними виробниками ринкових позицій на внутрішньому ринку.

Вагомий вплив на рівень цін на сільськогосподарську продукцію мають об'єктивні чинники кон'юнктури аграрного ринку - низькі доходи споживачів продукції, що звужують ємність ринку, посилення конкуренції на зовнішньому ринку і вимушене зниження цін для досягнення конкурентних переваг. Високий рівень монополізації сфери закупівель сільськогосподарської продукції в умовах неналежно сформованої інфраструктури аграрного ринку і проблемності пошуку альтернативних каналів збуту в поєднанні 3 впливом об'єктивних чинників кон'юнктури аграрного ринку призвели до високої мінливості цін на продукцію. За 2014-2018 роки індекси цін на зерно у відсотках до попереднього року формувались у діапазоні значень від 109,2\% в 2017 році до 156,6\% у 2015 році. При цьому значні обсяги зерна експортуються й індекси цін на нього складаються 3 урахуванням рівня цін зовнішнього ринку, де ціни порівняно із внутрішнім ринком стабільніші. Ширшим $є$ діапазон цін на продукцію, що виводиться переважно на внутрішній ринок. У вказаному періоді індекси цін на картоплю складались відповідно у діапазоні значень від 79,9\% у 2015 році до 127,1\% у 2017 році. Високі показники прибутковості виробництва періодично змінювались низькою прибутковістю і збитковістю (табл. 1).

\section{Таблиця 1}

Прибуток (+), збитки (-) у розрахунку на 100 грн поточних затрат на виробництво продукції у сільськогосподарських підприємствах України за 2014-2018 роки, грн

\begin{tabular}{lccccc}
\hline \multicolumn{1}{c}{ Продукція } & $2014 \mathrm{p}$. & $2015 \mathrm{p}$. & $2016 \mathrm{p}$. & $2017 \mathrm{p}$. & $2018 \mathrm{p}$. \\
\hline Зерно & 25,7 & 42,6 & 37,8 & 25,0 & 24,7 \\
Цукрові буряки & 17,8 & 27,7 & 24,6 & 12,4 & $-11,4$ \\
Картопля & 9,9 & 24,6 & 0,6 & 10,0 & 6,8 \\
Молоко & 11,1 & 12,7 & 18,6 & 26,9 & 16,1 \\
Велика рогата худоба на м'ясо & $-34,5$ & $-16,9$ & $-23,2$ & 3,4 & $-17,7$ \\
Свині на м'ясо & 5,6 & 12,6 & $-4,1$ & 3,5 & 6,9 \\
Яйця курячі & 58,8 & 60,9 & 0,5 & $-9,0$ & 5,4 \\
\hline
\end{tabular}

Адаптуватись до такої цінової нестабільності дуже складно. Неможливо розробляти обгрунтовані бізнесплани, маркетингові програми та інвестиційні проек- ти. Через високий ризик майже не залучаються банківські кредити. Переваги віддаються галузям зі швидкою окупністю капіталу. У найгіршому стано- 
вищі опинилось скотарство, де період окупності інвестицій є тривалим. Прибутковість виробництва молока в Україні у 2017 році була найвищою порівняно 3 іншими видами сільськогосподарської продукції, у 2018 році вона поступалась лише прибутковості виробництва зерна. Історично у переважній більшості нині економічно розвинутих країн монопольні тенденції у сфері закупівель та реалізації сільськогосподарської продукції долались створенням збутових кооперативів. Значні організаційні зусилля державних органів управління сільським господарством та громадських організацій, пряма фінансова підтримка не забезпечили в Україні помітного впливу збутових кооперативів демонополізації сфери закупівель і реалізації продукції. Найбільше зусиль спрямовувалось на створення збутових кооперативів у найбільш проблемній галузі, де ціни особливо мінливі - молочному скотарстві. Заготовлене кооперативами молоко збувається на молокопереробні підприємства за тими ж цінами, за якими молоко заготовлялось би і збувалось без створення кооперативу. Такі кооперативи лише спрощують діяльність молокопереробних підприємств із заготівель сировини. Життєздатними, такими, що здійснюють вплив на рівень цін і їхню стабілізацію $є$ кооперативи, які крім заготівель, здійснюють переробку молока та реалізацію молочних продуктів. При цьому формується саморегулівна вертикальна маркетингова система кооперативного типу. Тут без державного втручання формуються ціни, прийнятні як для сфери виробництва, так і сфери просування i реалізації кінцевому споживачу. Ціни оперативно переглядаються з урахуванням кон'юнктури ринку і проблем, що виникають на окремих рівнях збутового ланцюга. Значний вплив на загальний рівень і динамічні зміни цін мають результати аукційних торгів. Інформація про результати торгів впливає на рівень ціни, що складається за усіма іншими альтернативними каналами збуту продукції. Монопольні тенденції, що здійснюють окремі учасники ринкових відносин у сфері закупівель сільськогосподарської продукції, часто можливі лише через відсутність в окремих виробників продукції інформації щодо кон'юнктури ринку і можливої ціни в альтернативних каналах розподілу. Всі створені в Україні оптові ринки сільськогосподарської продукції мають постачальницький характер. Вони функціонують у великих містах i створюють умови для реалізації виробниками виробленої продукції, але вимагають здійснення торговельних операцій протягом мало не всього дня. Такі ринки більш прийнятні для посередницьких структур, які здійснюють комерційну діяльність у повному обсязі. Для виробників продукції прийнятніші оптові ринки збутового типу, які створюються у зонах виробництва сировини. Засновниками таких ринків, зазвичай, $\epsilon$ збутові кооперативи. Збутовими кооперативами на таких ринках можуть пропонуватись великі товарні партії однорідної продукції. Щодо такої продукції можуть організовуватись та здійснюватись аукційні торги.

Через високу цінову нестабільність постійне за 2014-2018 роки підвищення закупівельних цін на молоко поєднувалися зі скороченням поголів'я корів у сільськогосподарських підприємствах (рис. 1).

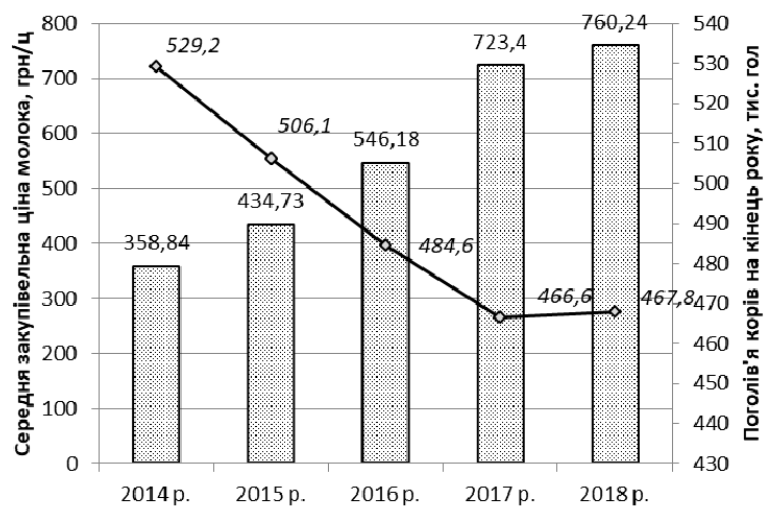

Середні ціни на молоко, реалізоване сільськогосподарськими підприємствами, гривень за центнер

$-\multimap$ Поголів'я корів у сільськогосподарських підприємствах України на кінець року, тис. гол.

Рис. 1. Закупівельні ціни на молоко та поголів'я корів у сільськогосподарських підприємствах України за 2014-2018 роки

Загальні обсяги виробництва молока в Україні за 2014-2018 роки скоротились 3 11,1 до 10,1 млн тонн. Вплив цінової волатильності на поголів'я корів та обсяги виробництва молока є вагомішими, ніж рівня цін. Цінова волатильність здійснює загальний і системний вплив на результати господарської діяльності та організаційну побудову сільського господарства. Не вдалось подолати загальну тенденцію скорочення поголів'я корів і зменшення обсягів виробництва молока розробкою та здійсненням програм державної підтримки молочного скотарства. Прискорено розвиваються особливо великі за розмірами суб'єкти господарювання голдингового типу, зорієнтовані на реалізацію продукції на зовнішньому ринку, де ціни стабільніші. У дискримінаційному становищі опинились невеликі виробники, які пропонують продукцію переважно на внутрішньому ринку. Майже не здійснюються закономірні процеси перетворення селянських господарств у господарства фермерського сімейного типу, хоч можливості такої трансформації передбачено відповідними доповненнями до Закону України "Про фермерське господарство".

Практики господарювання переважно оцінюють державну підтримку сільського господарства обсягами прямих фінансових дотацій. Пряма фінансова підтримка у даний час здійснюється на компенсаційній основі й не має впливу на загальні тенденції розвитку суб'єктів господарювання. При цьому з урахуванням вагомості впливу цінової волатильності на загальні результати господарської діяльності, проблемності вирішення більшості проблем, що нагромадились, навіть за умови збільшення обсягів прямої фінансової підтримки в мінливому ринковому середовищі зусилля державних органів управління сільським господарством варто спрямовувати насамперед на стабілізацію цін. Без такої стабілізації будь-які заходи державного регуляторного впливу лише част- 
ково послаблятимуть або посилюватимуть визначальний вплив ціни. Державні товарні й фінансові інтервенції, які здійснюються на організованому ринку, недостатні для загальної стабілізації цін.

Функцію стабілізації цін виконує ринок за умови його належної сформованості. Цінова нестабільність переважно $є$ результатом не стільки впливу об'єктивних ринкових чинників, скільки монопольних тенденцій окремих учасників ринкових відносин. Історично у переважній більшості нині економічно розвинутих країн монопольні тенденції у сфері закупівель та реалізації сільськогосподарської продукції долались створенням збутових кооперативів. Значні організаційні зусилля державних органів управління сільським господарством та громадських організацій, пряма фінансова підтримка не забезпечили в Україні помітного впливу збутових кооперативів на демонополізацію сфери закупівель і реалізації продукції. Зусилля насамперед спрямовувались на створення збутових кооперативів у найбільш проблемній галузі, де ціни особливо мінливі - молочному скотарстві. Заготовлене кооперативами молоко збувається на молокопереробні підприємства за тими ж цінами, за якими молоко заготовлялось би і збувалось без створення кооперативу. Такі кооперативи лише спрощують діяльність молокопереробних підприємств із заготівель сировини. Життєздатними, такими, що здійснюють вплив на рівень цін і їх стабілізацію є кооперативи, які, крім заготівель, здійснюють переробку молока та реалізацію молочних продуктів. При цьому формується саморегулівна вертикальна маркетингова система кооперативного типу. Тут без державного втручання формуються ціни, прийнятні як для сфери виробництва, так і сфери просування і реалізації продукції кінцевому споживачу. Ціни оперативно переглядаються з урахуванням кон'юнктури ринку і проблем, що виникають на окремих рівнях збутового ланцюга. Крім того, формуються порівняно великі товарні партії продукції, які можуть виводитись на обширні ринки. Кооперативи можуть здійснювати i експортні операції. Розширенням ринку збуту, виходом на нові ринки створюються можливості підвищення загального рівня ціни.

Підвищення ціни часто не $є$ самоціллю кооперативного формування. Збільшити загальну масу прибутку можна розробкою та здійсненням прийнятної маркетингової стратегії. Для порівняно великих господарських формувань прийнятною $є$ стратегія масового маркетингу, завдяки якій конкурентні переваги досягаються збільшенням обсягів товарних партій і за рахунок ефекту масштабу зниженням собівартості продукції та ціни на неї. Для посилення конкурентних переваг у розрахунку на одиницю продукції формується невеликий прибуток. Однак за рахунок збільшення обсягів продукції досягається загальна значна маса прибутку. При цьому вирішується проблема яка так і не була вирішена способами прямого державного регулювання ціни - знижується ціна на соціально значущі продукти. Прийнятною у вертикальних маркетингових системах кооперативного типу, що може здійснюватись на основі узгодження дій усіх учасників кооперації, є стратегія концентрованого маркетин- гу. Вона полягає у виробництві особливої продукції відповідно до вимог вузьких сегментів ринку. Таку продукцію, конкурентні переваги якої забезпечується ознаками відповідно до потреб цільових сегментів ринку, можна пропонувати за високими цінами. Розробкою та здійсненням прийнятних маркетингових стратегій досягається повніше задоволення потреб споживачів, що належить до різних сегментів ринку в поєднанні зі стабілізацією цін та належною прибутковістю суб'єктів господарювання.

Реалізація маркетингових стратегій є способом адаптації виробників продукції до ринкового середовища. Така адаптація можлива лише за результатами досліджень ринку та прогнозування ринкових тенденцій. Маркетингові дослідження охоплюють збір і обробку інформації, що включає рівень та очікувані зміни макроекономічних показників, даних, що характеризують стан ринків окремих видів продукції, оперативну кон'юнктуру інформацію. В умовах активізації міжнародних інтеграційних процесів необхідним є використання і даних, що характеризують тенденції, які складаються на міжнародному ринку. Кадрове забезпечення і фінансові ресурси окремих підприємств недостатні для здійснення таких досліджень. Необхідна державна підтримка сільського господарства, яка полягає у здійсненні маркетингових досліджень, доведенні результатів досліджень до учасників ринку. Така підтримка, що дозволяє виробникам продукції розробляти обгрунтовані маркетингові стратегії, є вагомішою, ніж пряма фінансова підтримка, яка тільки тимчасово послаблює фінансові проблеми підприємств.

Значний вплив на загальний рівень і динамічні зміни цін мають результати аукційних торгів. Інформація про результати торгів впливає на рівень ціни, що складається за усіма іншими альтернативними каналами збуту продукції. Монопольні тенденції, що формують окремі учасники ринкових відносин у сфері закупівель сільськогосподарської продукції, часто можливі лише через відсутність в окремих виробників продукції інформації щодо кон'юнктури ринку і можливої ціни в альтернативних каналах розподілу. Здійснення аукційних торгів є обов'язковою умовою набуття ринками сільськогосподарської продукції статусу оптових. Усі створені в Україні оптові ринки сільськогосподарської продукції мають постачальницький характер. Вони функціонують у великих містах і створюють умови для реалізації виробниками виробленої продукції, але вимагають здійснення торговельних операцій протягом майже не всього дня. Такі ринки більш прийнятні для посередницьких структур, які здійснюють комерційну діяльність на постійній основі. Для виробників продукції прийнятніші оптові ринки збутового типу, які створюються у зонах виробництва сировини. Засновниками таких ринків, зазвичай, є збутові кооперативи. Збутовими кооперативами на таких ринках можуть пропонуватись великі товарні партії однорідної продукції. Щодо такої продукції можуть організовуватись та здійснюватись аукційні торги. 


\section{Висновки}

Ціна $є$ центральним елементом ринкового механізму регулювання виробництва. У ціні, як у фокусі, концентруються майже всі економічні проблеми, i рівнем ціни визначаються темпи розвитку усіх галузей та підприємств. Вагомий вплив на рівень цін на сільськогосподарську продукцію мають об'єктивні чинники кон'юнктури аграрного ринку - низькі доходи споживачів продукції, що звужує ємність ринку, посилення конкуренції на зовнішньому ринку і вимушене зниження цін для досягнення конкурентних переваг. Високий рівень монополізації сфери закупівель сільськогосподарської продукції в умовах неналежно сформованої інфраструктури аграрного ринку і проблемності пошуку альтернативних каналів збуту в поєднанні 3 впливом об'єктивних чинників кон'юнктури аграрного ринку призвели до високої мінливості цін на продукцію. Адаптуватись до такої цінової нестабільності дуже складно - проблемно розробляти обгрунтовані бізнес-плани та маркетингові програми. В таких умовах знижується ефективність державної фінансової підтримки, яка лише частково послаблює проблеми, що нагромадились. Вагомий вплив на цінову стабілізацію має формування на кооперативних засадах вертикальних маркетингових систем, розробка та здійснення у них прийнятних маркетингових стратегій. Цим створюються саморегулівні системи стабілізації цін. Стабілізуючий вплив на рівень і динаміку цін здійснює організація аукційних торгів та поширення інформації про їх результати. Такі торги можуть організовувати на оптових ринках кооперативного типу, які доцільно створювати 3 участю державного капіталу в зонах виробництва сировини.

\section{References}

Bondarevska, K.V. (2014). Problema tsinovoho dysparytetu ta shliakhy yii vyrishennia $\mathrm{v}$ haluzi APK. Biznesinform, 8, 129-133. http://nbuv.gov.ua/UJRN/ binf_2014_8_23 (in Ukrainian).

Kovalenko, O.V., Slavov, V.P., \& Shubenko, O.I. (2013). Formuvannia rynkovoi tsiny produktsii pererobky moloka. Ekonomika APK, 7, 22-28. http://ir.znau.edu.ua/bitstream/123456789/3470/1/eko nomika\%20APK_2013_7_22-28.pdf (in Ukrainian).

Marmul, L.O. (2014) Sotsialni aspekty formuvannia tsin na silskohospodarsku produktsiiu u rehionakh Ukrainy. Naukovyi visnyk Khersonskoho derzhavnoho universytetu. Seriia "Ekonomichni nauky", 5, 209212. http://nbuv.gov.ua/UJRN/evzdia_2016_2_17 (in Ukrainian).

Rosokha, V.V., \& Sharapa, O.M. (2016). Instytutsiine zabezpechennia upravlinnia hospodarskoiu diialnistiu ahrarnykh pidpryiemstv. Ekonomika APK, 10, 73-82. http://nbuv.gov.ua/UJRN/E_apk_2016_10_12 (in Ukrainian).

Semenda, D.K., Semenda, O.V., \& Petruk, T.Yu. (2018). Ekonomichni aspekty funktsionuvannia silskohospodarskykh pidpryiemstv. Ekonomika APK, 10, 106116. http://nbuv.gov.ua/UJRN/E_apk_2018_10_14 (in Ukrainian).

Shpychak, O.M. (2016). Problemy tsinoutvorennia v konteksti kupivelnoi spromozhnosti naselennia ta infliatsiinykh protsesiv. Ekonomika APK, 8, 59-70. http://nbuv.gov.ua/UJRN/E_apk_2016_6_8 (in Ukrainian).

Uzhva, A.M. (2016). Tsinoutvorennia yak vazhlyvyi skladnyk mekhanizmu rozvytku rehionalnoho ahrarnoho biznesu. Natsionalna ekonomika: intelekt KhKhI, 5, 120-123. http://nbuv.gov.ua/UJRN/ int_XXI_2016_5_27 (in Ukrainian). 